\title{
An Extensive Listening Strategy to Develop Students' Listening Skill
}

\author{
Rosinta Norawati ${ }^{1, *}$ \\ ${ }^{1}$ Universitas Jambi, Jambi, Indonesia \\ ${ }^{*}$ Corresponding author. Email: norabutar@yahoo.com
}

\begin{abstract}
This paper informs a second stage of an action research study intended to develop students' listening skill through extensive listening strategy. Data were collected within listening achievement test, questionnaires, field notes and observation. The study comprised nine weekly-based interventions that involved planning, action, observation, and reflection. In Teaching listening process be situated as a combination of in-class and out-off class activity. The result showed that most of the students could go along with the strategy implemented, especially after the first stage. The questionnaire indicated that students' gave positive perception on each of elements of the questionnaire across the stages. From observation, the result proved that students participated actively in the implementation of this strategy, and the percentage of participation increased across the stages
\end{abstract}

Keywords: Extensive listening, Action Research, Listening Skill.

\section{INTRODUCTION}

In the Indonesian context, English is taught as a compulsory subject in junior and senior secondary school level, as well as at tertiary levels of education in both state and private schools. In Indonesia, English takes into consideration as a foreign language, a language which is learnt commonly in the classroom setting in order to be able to use it with any other English speakers, and not used as a second language since the existence of the language is low in one's surrounding [1]. In English, the way of teaching plays an important role. In general, students find small amount of English in the classroom while outside the classroom the English used is not instructional language, but a means of communication in social interaction.

Listening ability is important to acquire for Indonesian learners; but their English proficiency to understand the listening is still far from being adequate. University students, who had studied English for six years in the secondary school level (Junior and Senior High School), were still unable to understand spoken texts; except a small portion of them [2]. There are some reasons why the learners believe listening demanding. First, they have lack of attempt to understand each and every word while listening because they are incapable to assign their L1 skill easily to second language [3]. Second, they encounter problem in differentiating the pronunciation, accents as they put to one particular articulation and they still find difficulties to understand the meaning of the spoken text they hear [4]. The primary goal of listening subject for undergraduate students in Indonesia is to ease the students in interpreting of the spoken materials from the lower intermediate level to more advance ones. However, teachers keep an eye on developing listening comprehension by answering questions following the texts than to understand the spoken texts. Lacking pedagogical knowledge in listening instruction, teachers are more likely to apply the steps of "Listening, answering and checking" in spoken text to help students listen, students do not pay more attention to exploring listening at a theoretical level. students are not well prepared in terms of techniques and practices, which they can use in the classroom. [5]

This study reports the implemented strategy of extensive listening to develop students' listening skills in comprehending spoken discourse. This strategy would enrich teachers' knowledge of one model of teaching listening by which the English teacher could employ in their real class teaching activities. This study aim to investigate educational actoon as an example of systematic action research and can be carried out to improve the effectiveness of teaching listening. This research questions of this study 
(1) Can listening course be developed through extensive listening strategy to improve students' listening skills?

(2) What are students' perceptions toward the extensive listening strategy?

\subsection{Action research in language learning}

This study is intended to give contribution to the development of teaching listening strategy. An action research design is employed because it is one of the effective ways in advancing the quality of English teachers' performance in teaching instruction as well as students' achievement in learning English in classrooms. The action research for English language learning aims at developing a certain teaching strategy to solve practical teaching problems in English classroom [6]. There are some results of action research studies in terms of developing English language teaching classroom practice have been proved by earlier researchers. Uztosun et all [7] who conducted action research in Turkey, applied student negotiation in teaching speaking. They state that action research study promoted positive attitudes towards classes since students reported feeling appreciated and respected. Lo [8], who carried out an action research at one university in Taiwan, employs the Triarchic Intelligent Theory (Analytical, Creative, and Practical intelligence) in teaching English reading and writing, also states that action research advanced teaching quality through being self-critical towards the classroom procedures. Thus, this study utilized action research design to find strategy appropriate for listening teaching that match learners' listening skills and the strategy can help enhance the success in students' learning listening.

\subsection{Extensive listening in language teaching}

In language acquisition and language learning, listening is a $n$ essential part. The position of listening is generally put on the inner circle as 'listening-speakingreading-writing' sequence in language learning. The categorization assumes that reading and writing come after listening and speaking. Listening and speaking can hardly be separated, however, someone is assumed doing listening more than he performs speaking. From this statement, it could be determined that listening shows an important function in language acquisition and communication. Generally, listening is the ability to accurately obtain and decode messages in the interaction process and it includes more than just hearing or paying attention to what other people are saying. Listening has an important role in language learning, because listening is one of the four main skills in mastering language. Other skills such as speaking, writing and reading are equally important, but what distinguishes them is that these three things are used to acquire language, while listening is used for language knowledge.
The development of the theory in language learning brings about alterations in the approaches of language teachers towards listening. Some academics have defined listening to be defined as an active and complex process in which the listener must continuously construct meaning based on the message received. Listening is also sometimes referred to as a passive skill, where listening is a "constructive process in which students are active participants" [5].

According to Renandya \& Farell [9], Extensive Listening is one of the best ways to teach listening to get comprehensive input from students so that they can understand spoken texts and are stated as an essential aspect of the language learning process. listening was also defined as pleasure. Extensive Listening covers all aspects of listening activities that allow students to receive understandable propeller feedback. The most important thing in Extensive Listening is that the material that is heard must be meaningful so that students can benefit from it.

Nowadays, internet is becoming a great resource for finding listening material. however, the most important thing is how to find material that is understandable, meaningful, fun and appropriate to the level of the learner. Based on Waring (2003) said everything that involves text and material in Extensive Listening must be easily and fluently understood by students, without assignments or questions. In addition, Vo (2013) argued that the characteristics of Extensive Listening, namely students choose resources and materials that are considered suitable for their English proficiency, the material must also be fun, and not too difficult for students to understand the material. example from Extensive Listening, choosing programs on radio in English.

Many things are facilitated by extensive listening in foreign language learning. according to Krashen (1985), listening is the main source in obtaining language, one way of obtaining language is by understanding messages and receiving feedback. Thus it will help learners develop their language skill as the concept of extensive listening. Generally, extensive listening gives power to language learners since they can choose listening materials appropriate to their proficiency. In order to understand spoken text in order to acquire vocabulary, students must be in a peaceful mode and focus attention on what they hear. students can also learn other features of listening such as stress, intonation and pronunciation. in other words, extensive reading can increase a sense of success and motivation for students. 


\section{METHODOLOGY}

\subsection{Setting and participant}

The study was carried out in the listening for general purposes class of the second-year students at an English department of Universitas Jambi. The class had 27 students (11 male and 16 female). Before implementing the strategy, an initial study was carried out to see their listening achievement scores. They were given a listening test which consists of eight spoken texts and five listening skills (i.e. listening for main ideas, listening for details, listening for specific information, inferring meaning, and recognizing context). Their average score was 43.30 , and this score was still low, still has not reached the standard score of passing grades that was 60 points. 1

Criteria of success were set up to confirm whether the implementation of the strategy effectively improve students' listening ability. The study was considered successful if two conditions were met. First, it was indicated from the data resulting from students' score on the achievement test administered at the end of the cycle which showed improvement. The improvement referred to the improvement of students' score on the achievement test confirmed with their score in the preliminary study. The researcher applied the criteria of success based on teacher commonly used in the class. For undergraduate students, they are assumed passed the course if they get grade $\mathrm{C}$ which is equal to 60.00 . The mean score of the preliminary study was 43.30. Consequently, the researcher could safely assume that improvement of the students' listening ability would be significant if the students' achievement test could reach at least 16.70 points of improvement to get the passing grade 60 in the average. Thus, the study was considered successful if the mean of the students' score on the achievement test reached 17 points higher than the mean score in the preliminary study; or the average score of the achievement test was 60 as a requirement to be able to pass the course. Second, students were keenly participated in the teaching learning process during the implementation of the process-based extensive listening strategy. It was reflected when students gave good response on each stage as indicated in the observation checklist. To determine the category of students' participation in the classroom was based on the number of students actively participated during the process of teaching and listening in the class, for example, there were 27 students participated, if all students involved, 27 students, they were categorized as very good in participating the process of teaching. Thus, the researcher could safely assume that they enjoyed doing the listening activities given by the teacher and felt that extended listening strategy could help them understand spoken text better.

\subsection{Data collection and analysis}

There were four data collection tools were employed in this study; listening test, questionnaire, field notes and observations. This was a collaborative research which meant the researcher on this study acted as a participatory practitioner. The teacher who teaches in the class acted as the practitioner and assisted the researcher in preparing the teaching process that would be applied in the classroom; administering the listening test, and the questionnaire. The researcher with the help of a teacher as a collaborator did the planning. In planning, the researcher prepared the processes of teaching listening, adopted the teaching materials, the lesson plan, and criteria of success which suit the students' need.

In implementing the action, the researcher and the teacher worked together in applying the strategy. The researcher's part was to monitor the activities of students in the classroom, where the teaching process in the classroom was completed by the teacher. Then, the researcher who represented as observer viewed the implementation of action in the classroom by using observation checklists and field notes. After implementing the strategy the researcher and the collaborator teacher evaluated the implementation and discussing the possibility of modifying the strategy if the strategy could not meet the criteria of success. The phase process ended whenever the problems had been solved or the criteria of success had been achieved.

In order to control any gain in listening proficiency after the implementation of this strategy, the listening achievement test were administered to the students. The purpose of giving this test was as a validation to any claims of listening improvement made by students, and to verify the student reports of improvement in listening ability as a result of applying the strategy. The test was directed two times. The first test was given after three meetings of the implementation, and the second test was given after the next three meetings before this stage ended.

The reason for taking questionnaire as one of data collection instruments' was to measure beliefs, attitudes, preferences, and behaviors, and the questionnaire more effective tools to be used [10][11]. In addition, it was more practical in administering and it tolerated informants to be performed with a standardized incitement and it helps to lessen unreliability on the part of researcher [5]. The questionnaire was given two times; after the first implementation, and after the second implementation. The focus of the questionnaire was to see the students' perception after the implementation of the strategy of each phase. The questionnaire consisted of 20 statements that involve three parts. The first part was referring to the students' listening ability which contained seven statements. The statements were about how the students' feel after they were taught the 
extensive listening strategy. The second part which comprises six statements was stating the listening component of the class. This section asked how students perceive teacher's performance in the class. The third part was about the students' activity beyond the class where the statements were about the students' activities on applying an extensive listening activity beyond the class as an autonomous learning. Likert scaled options of the questionnaire were divided into four; strongly disagree, disagree, agree, and strongly agree. In order to counterbalance any bias, the options were ordered from left to the right, starting from strongly disagree to strongly agree. Each scaled option was assigned a numerical value described as follows; strongly disagree (1), disagree (2), agree (3), and strongly agree (4). The total number of values was used to compute average scores for each statement of the questionnaire. The total numbers of respondents for each item were used to create charts to analyze comparison between different responses to each item, and between the different dimensions of the questionnaire.

Field notes was employed to record the factual data on the students' activities that reflected the students' participation during the teaching and learning of listening by implementing extensive listening strategy. Any phenomena during the teaching learning process, which could not be recorded through observation checklists, were recorded on field notes. The data obtained would be analyzed interpretatively to find out whether the implementation of the strategy was successful or not.

Another source of data was observation checklists, as subjective perception can be avoided by gathering data from different distinct point [12] [13]. The observer recorded the students' involvement during the teaching learning process in which the strategy was implemented in the class, such as students' attention to the teacher's explanation, students' respond to the teacher's question, students' willingness to do the activity in the class, and students' ideas related to the topic

\section{IMPLEMENTING EXTENSIVE LISTENING STRATEGY}

There were two phases of this stage; the first phase and the second phase, and each phase comprised three time teachings. After each phase had been completed, then the students were given a listening test and a questionnaire.

This study was conducted in a language laboratory so the teaching listening process can run steadily without any interruption from outside of the class. It took nine meetings to apply this strategy for this class including the preliminary study (first meeting), first-test (fifth meeting) and second-test (ninth meeting). At the first meeting the students were introduced about extensive listening strategy, what it was, and how it was accomplished during the study. After all the matters pertaining to the study were explained, then the students were given a listening comprehension test as the initial study. The following was a description of teaching activity in class.

Before starting the lesson at the second meeting of the first teaching, teacher had to prepare all the things regarding to the teaching and learning process (prior to class part). He had to set up the process and strategy to teach. In accordance with the design that had been determined in this study, in-class section consisted of three parts; they are warm-up activity, main-activity, and follow-up activity. Thus, teacher had to follow the steps. And, in addition, teacher always made students' groups discussion in applying this activity. The following was an example of teacher teaching in the class.

The topic of this listening teaching was 'A Terrible Journey'; listening focus was predicting and listening for details; Activity type was ordering pictures. Because the main purpose of this study was to generate students' background knowledge on one topic by applying topdown processing, thus in warm-up activity teacher should cleverly dig up information about it. To start warm-up activity, teacher wrote 'Travel' on the board. Then, teacher encouraged students to call out various ways people travel. Next, teacher made students into group of four and tell them to compare the various ways of travelling. Then he asked them to list all the stages involved in travelling by plane, from arrival at the airport to passing through immigration control at the destination. After that, teacher reviewed all stages on the board by asking one student from each group to mention their result of discussion. Then, teacher told his own experienced travelling by plane when he went overseas. This activity ended with checking students' vocabulary. Teacher spelled out some words, and asked for the meaning. If the students did not know the words he mentioned, teacher wrote those words on the board and explain them. Once warm-up activity completed, teacher step up to the next activity, and that was main activity.

In main activity, teacher told students to think of some problems that may happen when travelling by plane, such as delayed flight, lost luggage, etc. After several students responded to it, then teacher divided them into groups of four. Then teacher gave each group a set of picture cards. He, furthermore, explain that they were going to listen to a woman talk about a terrible journey by plane, and that they must put the pictures in the correct order. Teacher gave them time to study the pictures, and told them to try to predict the correct order. After that, teacher played the recording, monitored each group to see how many have put the pictures in the correct order. Teacher played the recording again. If the students felt two times listening was not enough, they may listen again to the recording. Finally, teacher and students checked the answer 
In follow-up activity, teacher told students to think about the journey they remembered, and gave each student time to think and make notes of their story. Then, teacher put them into groups of four and asked them to tell their stories in groups. At the end, mix group and tell students to use their notes to repeat the stories they heard.

Before closing the class, teacher provides one topic for the students to assign where the topic given is the same topic they will learn for the following meeting. They are required to find out and search listening material related to the given topic from available sources both online and offline. Then, students are chosen randomly and asked them to tell briefly in front of the class the material they obtain.

\section{FINDING AND DISCUSSION}

Dealing with the finding of this study, the result obtains from listening test of the stage as follows;

Table 1 Students' score and the improvement point

\begin{tabular}{|c|c|c|c|c|c|}
\hline $\mathbf{N}$ & Preliminary Score & Achievement test 1 & $\begin{array}{c}\text { Improvement } \\
\text { point }\end{array}$ & $\begin{array}{c}\text { Achievement } \\
\text { test 2 }\end{array}$ & $\begin{array}{c}\text { Improvement } \\
\text { point }\end{array}$ \\
\hline 27 & 43.30 & 52.09 & 8.78 & 71.36 & 28.07 \\
\hline
\end{tabular}

Table1 indicates that there was an improvement on implementing extended listening strategy. Starting from the preliminary study where the students' average score was 43.30 which means the result is far from satisfaction, at that point, extended listening strategy was implemented to them. After the implementation in phase 1 , the students were given the first test to see whether the implementation influenced their listening skill. From the data obtained, it could be seen that their average score was increased, although the upturn was not much, from 43.30 to 52.09 , and the improvement point was 8.78 points in average. Next, after the implementation in phase 2 , the second test was given, and the average score was 71.36, and the improvement point was 28.07. Thus, the result met the criteria of success that was determined before, 17 points. The improvement point after the second phase was bigger than the criteria of success. Referring to the criteria of success determined before on this study, the strategy was considered successfully applied to the students because the mean of the students' score on the achievement test of the second phase reached more than 17 points higher than the mean score in the preliminary study.

Based on observation checklists and field notes of phase I, it could be said that the students' participation during the implementation of extended listening strategy from the first teaching in the listening teaching activities had improved, but not much because there were some students who did not look enthusiastic to participate when this strategy was implemented. The students' participation achieved good level. Observation of phase II indicated that the students had been active during the teaching and learning process. Everything went smoothly and students' participation was ultimately very high as analyzed from the data in the observation checklist. The observation revealed a great deal of improvement on students' involvement. It was indicated by the data found during the teaching learning process in the meetings. The students' participation achieved very good level

\subsection{Students' Perception on Their Listening Ability}

There were seven statements regarding to the improvement of students' ability. From data collected, with regard to learners' perception of the improvement their listening ability, it can be concluded that students gave positive responses to the implementation of this strategy. Figure 1 shows close consistency of responses relating to various improvements across the phases. Percentage of student responses through all two phases remained increased, varying of $9 \%$ at most. Furthermore, a reasonably reliable conclusion can be drawn that students' listening ability improved as the result of the class activities, and the improvement reached to 16.11 points across the phases. The teacher's explanation, listening materials, and practices and activities in class were also the contributing factors in the improvement of students' listening ability. 
Figure1 Students' perception on their listening ability

\begin{tabular}{|c|c|c|c|c|c|c|c|}
\hline 100.00 & 85.19 & 84.26 & 86.11 & 89.81 & 86.11 & $82.41^{89.81}$ & 90.74 \\
\hline 80.00 & 74.07 & 76.85 & 75.00 & & & & \\
\hline 70.00 & & & & & & & \\
\hline 60.00 & & & & & & & \\
\hline 50.00 & & & & & & & \\
\hline 40.00 & & & & & & & \\
\hline 30.00 & & & & & & & \\
\hline 20.00 & & & & & & & \\
\hline 10.00 & & & & & & & \\
\hline & $\begin{array}{c}\text { I like } \\
\text { listening to } \\
\text { English }\end{array}$ & $\begin{array}{l}\text { I feel } \\
\text { confident } \\
\text { when } \\
\text { listening to } \\
\text { English }\end{array}$ & $\begin{array}{l}\text { My listening } \\
\text { ability } \\
\text { improve a } \\
\text { result of this } \\
\text { class }\end{array}$ & $\begin{array}{l}\text { my listening } \\
\text { ability } \\
\text { improved as a } \\
\text { result of my } \\
\text { teacher's } \\
\text { explanation }\end{array}$ & $\begin{array}{l}\text { My listening } \\
\text { ability } \\
\text { improved as } \\
\text { the result of } \\
\text { listening } \\
\text { materials } \\
\text { used in class }\end{array}$ & $\begin{array}{l}\text { I do practice } \\
\text { listening } \\
\text { outside of } \\
\text { class }\end{array}$ & $\begin{array}{l}\text { My listening } \\
\text { ability } \\
\text { improved as } \\
\text { the result of } \\
\text { listening } \\
\text { practices and } \\
\text { activities in } \\
\text { class }\end{array}$ \\
\hline \multicolumn{8}{|c|}{ = Phase 1 Phase 2} \\
\hline
\end{tabular}

Of the aspect I like listening to English shown in Figure 1, students' response was the lowest in percentage among the seven statements, it was $74.07 \%$ on the first phase although they were majoring in English. However, at the second phase, it was increased to 85.19 point, and the increasing point was 11.12 point. Their perception has changed after the implementation of extended listening strategy. The same thing happens to the aspect of I feel confident when listening to English, students perception increased after the strategy was implemented to them. The interesting point of this questionnaire was students' perception of practicing listening outside the class, it got the highest percentage in the first phase, it was $82.41 \%$, and in the second phase it increased to $89.81 \%$, and the increasing point was $7.4 \%$ across the phase. It implied it was necessary for students to have an extra activity outside the class.

\section{LIMITATIONS}

This present study was carried out in particular class, thus findings revealed of this study cannot automatically be simplified to other situation. However, teachers may characterize some connections with their own context and be able to use findings and implications to adjust their instructions in arranging listening activities. The limitations do not necessarily reduce the contribution of this study in developing practices of teaching listening, but convey topics to think in the future research. In addition, the role of students at different proficiency levels and of different ages could also be investigated.

\section{CONCLUSION AND IMPLICATION}

The major purpose of this study was to develop students' listening skill through implementing the extensive listening strategy. As this study took place at a university, this strategy has implications for the students especially for them who took listening subject. The findings of this study suggested that teachers have to change the way they teach English, from the standard comprehension-based 'listen, answer, check' approach to more innovative strategy. Participants of this study have a preference to developing their listening strategies by asking them to explore their listening skills. They viewed this type of strategy were helpful for their future in which they will need to understand and interact in natural listening situation. Strategy selected by teachers could help students to learn with the variety of texts available for applying in class. The evaluation to see the students' listening skills showed that students place a high priority on achievement scores.

Teacher may want to get the students with various types of listening texts, the use of class time to develop listening abilities, and all strategies were important because the classroom is one of the places where the students have meaningful contact with learning language situation. In addition, for listening practices beyond the class with online materials were reachable for independent and motivated learners. Listening methodology can be altered through pedagogic involvement that introduced new, innovative teaching approaches and techniques in listening subject. When teachers have adequate knowledge about listening and the various pedagogic approaches used to develop listening abilities, intervention such as extended listening strategy of this current study was possible.

Classroom action research intervention is applicable to advance the field of teaching listening. The guiding frame work introduced in this study can be applied by individual teacher for their individual class. This strategy 
and the application to listening instruction give beneficial contribution to the field of language teaching. For any listening teacher researcher who want to product-oriented approaches to listening, this strategy provides a theoretical-grounded frame work for a process-oriented strategy based approach methodology for listening.

Mentioning the implication that are derived from the research findings onto the teaching of listening, it is necessary to recall what situational backgrounds have motivated the researcher to carry out this present study. It has started from students' practical problem in taking listening courses where the researcher feels that the teaching listening comprehension is needed to improve. The present study has been an effort whereby an improvement in the teaching of listening comprehension could be expected by implementing extended listening strategy. In spite of the fact that the study has produced an inconclusive result, practical implication pertinent to the situational backgrounds of the study are by no means impossible. In fact, as far as situational implications are concerned, the result of the study is not the only decisive factor. Indeed, the researcher can depend both on the product and the process of the empirical proceeding.

\section{REFERENCES}

[1] Harmer, J. 2007. The practice of English language teaching. ( $4^{\text {th }}$ ed.). Pearson Longman

[2] Gunarwan, A. 1998. Kedudukan dan fungsi bahasa asing di Indonesia dalam era globalisasi. A paper presented in the Kongress Bahasa Indonesia VII. Jakarta: Departemen Pendidikan dan Kebudayaan

[3] Cross, J. 2012. Listening Strategy Instruction (or Extensive Listening?): a response to Renandya (2012). ELTWO. ELTWorldOnline.com

[4] Richards, J.C. 2015. Second Thoughts on Teaching Listening. RELC, 36/1: 85-92

[5] Siegel, J. 2015. Exploring Listening Strategy Instruction Through Action Research. Palgrave: Macmillan

[6] Latif, A. 2013. Research Methods on Language Learning. State University of Malang Press

[7] Uztosun, M.S., et al,. 2014. An Action research study designed to implement student negotiation to improve speaking classroom practice in Turkey. Educational Action Research Journal 22/4, 488-504

[8] Lo, W. 2009. "An Application of the Triarchic Theory of Intelligence to Students of English in a Taiwanese University: Reflections of an Action Research” EdD diss., Durham University
[9] Renandya, W., \& Farrell, T. 2011. Teacher, The tape is too Fast! : Extensive Listening in ELT. ELT Journal 65/1: 52-59

[10] Dornyei, Z. 2007. Research methods in applied linguistics. Oxford: Oxford University Press

[11] Burns, A. 2010a. Doing Action Research in English Language Teaching: A Guide for Practitioners. New York: Routledge

[12] Hopkins, D. 2009. A teacher's guide to classroom research $\left(4^{\text {th }}\right.$ ed.). Berkshire, UK: Open University Press

[13] Burns, A. 1999. Collaborative action research for English language teachers. Cambridge: Cambridge University Press 